\title{
AN ANALYSIS OF FOREST GROWTH FEATURES OF LOW-PRODUCTIVE GREY FOREST SANDY SOILS OF UKRAINE WITH REGARD TO THEIR RELEVANCE FOR FOREST CULTIVATION
}

\author{
Peter Kijovský ${ }^{1}$, Anatoliy Lisnyak ${ }^{2}$, Kateryna Utkina ${ }^{3}$, \\ Alexey Kraynukov ${ }^{4}$, Eva Michaeli $^{5}$
}

\begin{abstract}
A comparative analysis of the forest growth features of low-productive grey forest sandy soils of the Polissia, the Forest-Steppe and the Northern Steppe of Ukraine was performed. Although grey forest soils from different natural zones are distinguished in the genesis of their soil rocks, as well as typical and zonal belongings, at the same time they are united by an important general characteristic, light texture, determining the similarity of physical, physico-chemical and agrochemical indicators and, in general, forest site capacity. A package of markers to assess the forest site capacity of sandy soils (pine habitats) with such soil quality indicators as the content of physical clay, the coarseness of the humified layer of soil profile and $\mathrm{K}_{2} \mathrm{O}$ content was revealed.
\end{abstract}

UDC Classification: 502.3/.7, DOI: 10.12955/cbup.v7.1480

Keywords: forest, low-productive soils, sandy rocks, clay, humus

\section{Introduction}

Problems related to the study of the properties of forest soils and their influence on the productivity of forest stands and the determination of tree-growing potential of forest habitats have always been important areas of study in silvics and forest soil science done by many domestic and foreign researchers (Zonn, 1987; Karpachevsky, 2004; Bautista-Cruz, 2012; Błońska, 2013; Medvedev, 2006; Lisnyak, 2013). The fact that the knowledge and acceptance of soil properties predestines the landscape for different ways of its use is mentioned also in the papers by Vilcek \& Koco (2018), Vilcek (2011,2013a), and Vilcek et al. (2019). Since the afforestation on low-productive sandy soils is a difficult task due to the harsh, mostly extreme conditions for tree species, its effectiveness depends on many factors, in particular the objective determination of the level of land usability for afforestation.

In Ukraine, for the assessment of forest site capacity and edaphic conditions of habitats, the method of phytoindication (by species composition and productivity of forest phytocoenoses) is used. Its essence is reflected by a classification scheme of forests and forest habitats, Alekseev-Pogrebnyak edaphic grid of habitats. However, in artificially grown forests of natural zones, in particular in the Steppe one, where forest vegetation is azonal, the set of plant indicators is mainly limited by the state of tree stands, and in treeless areas, by characteristics of grass vegetation (species composition, projective cover), which are not always effective. Thus, the most informative and objective indicator of the forest site capacity are soil properties. Numerous unsuccessful attempts to afforest sandy soils make it necessary to study them and determine markers of the relevance for forest cultivation (Tokavchuk 2011; Rogovsky 2008). Work Objective: to determine diagnostic indicators (and their quantitative parameters) for the assessment of the level of relevance for forest cultivation of low-productive sandy soils transferred for afforestation to forestry enterprises in the Polissia, the Forest-Steppe and the Northern Steppe of Ukraine.

\section{Materials and methods}

The subjects of research are lands transferred to forestry enterprises for afforestation in the Polissia, the Forest-Steppe and the Northern Steppe of Ukraine. The study of soil relevance for forest cultivation was based on the principles of forest typology and comparative ecology using the methods of phytoindication, as well as field and analytical laboratory methods of soil investigation. Soil characteristics were determined in compliance with the following national standards of Ukraine: watersoluble ions in soils (DSTU 26425-85), pH (DSTU ISO 10390:2007); granulometric composition (DSTU 4730:2007), values of actual and potential acidity (DSTU 7537:2014), total humus content (DSTU 4289:2004) and the common forms of NPK (GOST 26715-85, GOST 26717-85 and GOST

\footnotetext{
${ }^{1}$ University of Presov, Faculty of Management, Presov, Slovakia, agrofarmamedzany@gmail.com

${ }^{2}$ V. N. Karazin'Kharkiv National University, Kharkiv, Ukraine, ecointernational@karazin.ua, G. N. Vysotsky

Ukrainian Research Institute for Forestry and Forest Amelioration, Kharkiv, Ukraine, anlisnyak@gmail.com

${ }^{3}$ V. N. Karazin'Kharkiv National University, Kharkiv, Ukraine, ecointernational@karazin.ua

${ }^{4}$ V. N. Karazin'Kharkiv National University, Kharkiv, Ukraine, ecointernational@ karazin.ua

${ }^{5}$ University of Presov, Faculty of Humanities and Natural Sciences, Presov, Slovakia, eva.michaeli@unipo.sk
} 
26718-85). The collection and preparation of soil samples for analyses was carried out according to GOST 28168-89 and DSTU ISO 11464-2001. Statistical processing of the obtained results was performed by the method of analysis of variance with the aid of MS Excel.

To achieve this goal, the following tasks were solved: combining with the state of forest plantations established during different years on low-productive sandy soils of varying levels of development, forest growth features of these soils were studied. On this basis, the markers of their relevance for forest cultivation were determined.

\section{Results}

We performed a comparative analysis on the most common soils of light texture in Ukraine, namely grey forest soils on fluvioglacial / glacial sands, which are zonal soils of the Polissia, and grey forest soils on ancient alluvial sands formed in the Forest-Steppe and the Northern Steppe, where mainly a pine series of habitats is developed.

It should be noted a sufficient similarity of the particle size distribution (granulometric composition) of the studied soils in almost all fractions, with the exception of the coarse dust fraction, in which the greatest difference was found (Table 1). So, the Polissia soils are characterized by its maximum content, $5.4 \%$, whereas in the Forest-Steppe the content is reduced to $2.9 \%$, that is, almost half, and in the Northern Steppe its content is reduced to $1.5 \%$, or about $1 / 4^{\text {th }}$ what was seen in Polissia soils. The increased content of coarse dust in the soils of the Polissia indicates active destruction of mineral grains (primarily feldspar), which accumulate in this fraction (Pogozhev, 2006). In areas of insufficient moisture, the Forest-Steppe and especially the Northern Steppe, this process slows down.

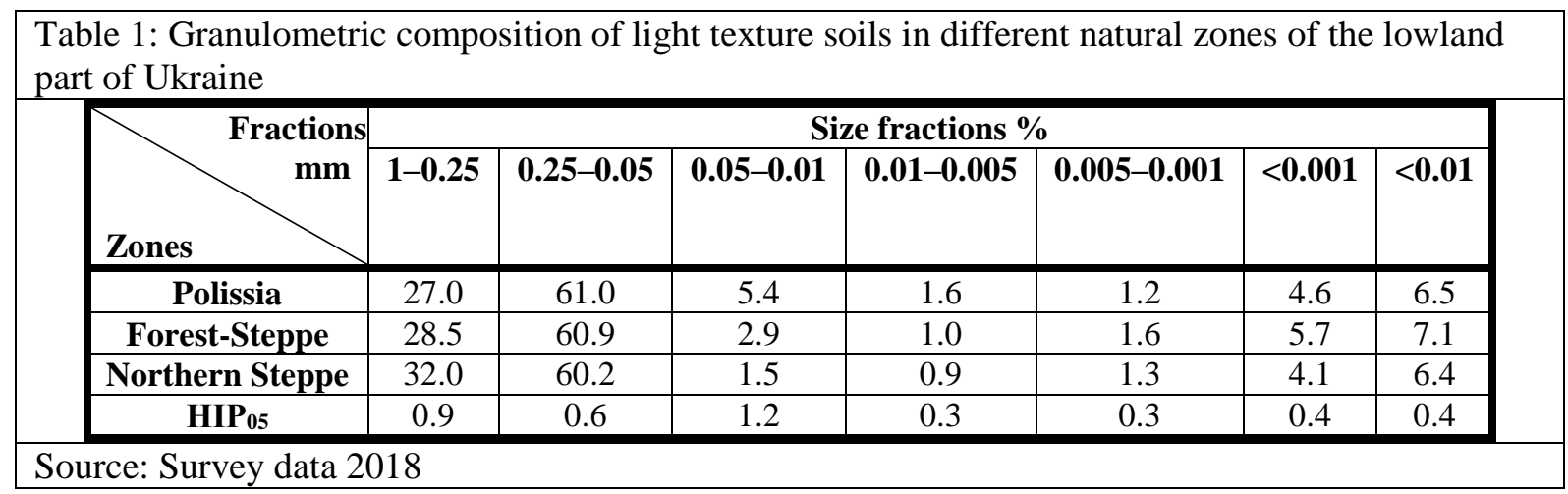

Table 2: Average content of physical clay, coarseness of the humified layer of soil profile and $\mathrm{pH}$ of light texture soils over soil profile

\begin{tabular}{|c|c|c|c|c|}
\hline Soils & $\begin{array}{l}\mathrm{pH} \\
\left(\mathrm{H}_{2} \mathrm{O}\right)\end{array}$ & $\begin{array}{l}\text { pH } \\
(\mathrm{KCl})\end{array}$ & $\begin{array}{l}\text { Physical clay } \\
\text { content, \% }\end{array}$ & $\begin{array}{l}\text { Coarseness of the humified } \\
\text { layer of the soil profile, } \mathrm{cm}\end{array}$ \\
\hline Grey forest soils, Polissia & $\begin{array}{l}5.1 \pm 0.08 \\
(n= \\
145)\end{array}$ & $\begin{array}{l}4.2 \pm 0.11 \\
(n= \\
101)\end{array}$ & $\begin{array}{l}6.5 \pm 0.42 \\
(n=176)\end{array}$ & $\begin{array}{l}26 \pm 3.2 \\
(n=75)\end{array}$ \\
\hline $\begin{array}{l}\text { Grey forest soils, Forest- } \\
\text { Steppe and Northern } \\
\text { Steppe }\end{array}$ & $\begin{array}{l}5.1 \pm 0.07 \\
(n= \\
180)\end{array}$ & $\begin{array}{l}4.2 \pm 0.12 \\
(n=89)\end{array}$ & $\begin{array}{l}7.1 \pm 0.51 \\
(n=144)\end{array}$ & $\begin{array}{l}34 \pm 7.1 \\
(n=57)\end{array}$ \\
\hline HIP01 & 0.18 & 0.21 & 0.57 & 6.31 \\
\hline HIP05 & 0.11 & 0.18 & 0.43 & 5.27 \\
\hline Average for both soils & $\begin{array}{l}5.1 \pm 0.07 \\
(n= \\
325)\end{array}$ & $\begin{array}{l}4.2 \pm 0.11 \\
(n= \\
190)\end{array}$ & $\begin{array}{l}6.8 \pm 0.29 \\
(n=320)\end{array}$ & $\begin{array}{l}29 \pm 2.7 \\
(n=132)\end{array}$ \\
\hline
\end{tabular}

Source: Survey data 2018

Grey forest soils of the Forest-Steppe are characterized by the maximum content of physical clay, $7.1 \%$, which is $15 \%$ higher than in the soils of the same type in the Northern Steppe and is 14\% higher than in the grey forest soils in the Polissia. As to acidity, all the soil types studied, regardless of their zonal belonging, are characterized by a weakly acidic reaction of the medium with the same average actual acidity, $\mathrm{pH}=5.1$, and potential (exchangeable) acidity, $\mathrm{pH}=4.2$ (Table 2) over the soil profile. Another 
indicator, the content of total phosphorus, is identical in the studied soil types, $0.04 \%$. Among the main nutrients (NPK), its content is the lowest, which proves the extreme poverty of light texture soils for phosphorus compounds. For the remaining indicators (coarseness of the humified layer of the soil profile, the contents of humus, nitrogen and potassium), there is a difference among the soils of the regions (Table 3).

Table 3: Average content of total humus and common forms of NPK in the light texture soils over soil profile

\begin{tabular}{|c|c|c|c|c|}
\hline Soils & Humus & $\mathbf{N}$ & $\mathbf{P}$ & $\mathbf{K}$ \\
\hline Grey forest soils, Polissia & $\%$ & & & \\
\hline $\begin{array}{l}\text { Grey forest soils, Forest-Steppe and Northern } \\
\text { Steppe }\end{array}$ & $\begin{array}{l}0.83 \pm 0.066 \\
(n=225)\end{array}$ & $\begin{array}{l}0.05 \pm 0.003 \\
(n=179)\end{array}$ & $\begin{array}{l}0.04 \pm 0.004 \\
(n=179)\end{array}$ & $\begin{array}{l}0.07 \pm 0.003 \\
(n=179)\end{array}$ \\
\hline HIP $_{01}$ & $\begin{array}{l}1.62 \pm 0126 \\
(n=152)\end{array}$ & $\begin{array}{l}0.06 \pm 0.004 \\
(n=170)\end{array}$ & $\begin{array}{l}0.04 \pm 0.003 \\
(n=170)\end{array}$ & $\begin{array}{l}0.09 \pm 0.007 \\
(n=170)\end{array}$ \\
\hline HIP $_{05}$ & 0.18 & 0.008 & 0.007 & 0.012 \\
\hline Average for both soils & 0.14 & 0.006 & 0.005 & 0.009 \\
\hline
\end{tabular}

Source: Survey data 2018

Humus content in grey forest soils of the Forest-Steppe and the Northern Steppe is almost twice as high as in the Polissia soil, and the coarseness of humified layer of soil profile and potassium and nitrogen contents are higher by 45,32 and $20 \%$, respectively.

The difference in these indicators is primarily due to the peculiarities of the natural climatic conditions, in which the types of studied soils have been developed. The conditions typical for the Polissia are lowland terrain, temperate continental climate with warm and humid summers and mild winters, significant watering of the territory owing to a dense river network with wide valleys, the dominance of washing type of soil water regime, which causes an active process of destruction and leaching organic and mineral substances from the soil profile. That is why Polissia grey forest soils, compared with the soils of the Forest-Steppe and the Northern Steppe, are marked by a slightly lower trophic level, at the same time they are better supplied with moisture, as a result of which its forest site capacity become level.

The similarity of productive capacities of these soils is evidenced by their forest growth effect, that is, the formation of fairly productive pine forests on them. Note that a sufficient supply of soil moisture during the growing season is a more important factor affecting the productivity of pine forests than deficiencies of several nutrients. This is determined, on the one hand, by the general exactingness of tree species on soil moisture, and on the other, to the high tolerance of Scots pine, Pinus sylvestris, to low habitat trophicity. Thus, despite the fact that the studied soils differ in type and zonal belongings, as well as the genesis of their soil rocks, they are united by a very important general characteristic, light texture, determining the similarity of their forest site capacity.

\begin{tabular}{|c|c|c|c|c|c|c|}
\hline \multirow[t]{2}{*}{ Indicators } & $r^{I}$ & $t^{2}$ & $r$ & $t$ & $r$ & $t$ \\
\hline & \multicolumn{2}{|c|}{$\begin{array}{c}\text { Grey forest soils, } \\
\text { Polissia }\end{array}$} & \multicolumn{2}{|c|}{$\begin{array}{c}\text { Grey forest soils, } \\
\text { Forest-Steppe and } \\
\text { Northern Steppe }\end{array}$} & \multicolumn{2}{|c|}{$\begin{array}{l}\text { Average for both } \\
\text { soils }\end{array}$} \\
\hline $\mathrm{pH}\left(\mathrm{H}_{2} \mathrm{O}\right)$ & -0.21 & - & -0.06 & - & -0.09 & - \\
\hline N content & 0.16 & 1.82 & 0.22 & 2.66 & 0.26 & 4.42 \\
\hline $\mathrm{P}_{2} \mathrm{O}_{5}$ content & 0.22 & 3.03 & 0.65 & 10.03 & 0.29 & 4.94 \\
\hline$K_{2} O$ content & 0.76 & 14.41 & 0.77 & 13.13 & 0.76 & 18.54 \\
\hline $\begin{array}{l}\text { Coarseness of the humified } \\
\text { layer of the soil profile }\end{array}$ & 0.68 & 3.32 & 0.78 & 8.71 & 0.73 & 8.87 \\
\hline Humus content & 0.36 & 4.58 & 0.43 & 4.77 & 0.43 & 7.86 \\
\hline
\end{tabular}

Notes: ${ }^{1} r$ is the correlation coefficient,${ }^{2} t_{05}$ is the materiality qualifier $(n=80 \div 260)$

Source: Survey data 2018

Let us consider the relationships among the content of physical clay (PC) and a number of soil quality indicators (coarseness of the humified layer of soil profile, humus content, the general forms of NPK 
and $\mathrm{pH}$ value). In both types of soil, a close correlation was found for total potassium and coarseness, a moderate one for humus and a weak one for nitrogen and $\mathrm{pH}$. The relationship of phosphorus with physical clay content in sod-podzolic soils is weak, and in soddy podzolized soils is moderate (Table 4). Close connection between the average values of the content of physical clay and the coarseness of the humified layer of the soil profile $(r=0.73)$ for both types of the studied grey forest soils (on fluvioglacial sands and ancient alluvial sands), as well as between the average values of physical clay and total potassium $(r=0.76)$ allowed us to conduct a regression analysis between these indicators, the results of which are shown in Table 5.

Table 5: Regression dependence of several indicators of light texture soil quality on physical clay
content $(x)$
\begin{tabular}{|l|c|c|c|c|}
\hline $\boldsymbol{Y}$ & $\boldsymbol{r}^{\mathbf{I}}$ & $\boldsymbol{t}^{\mathbf{2}}$ & $\boldsymbol{n}^{\mathbf{3}}$ & Regression equation \\
\hline $\mathbf{K}_{\mathbf{2}} \mathbf{O}$ content, $\%$ & 0.76 & 18.54 & 135 & $y=0.012 x-0.018$ \\
\hline Coarseness of the humified layer of the soil profile, $\mathbf{c m}$ & 0.73 & 8.87 & 78 & $y=6.25 x-15.72$ \\
\hline
\end{tabular}

Notes: ${ }^{1} r$ is the correlation coefficient, ${ }^{2} t_{05}$ is the materiality qualifier, ${ }^{3} n$ is the data sample

Source: Survey data 2018

Consequently, an increase in physical clay content in soils of light texture by $1 \%$ (within PC content range from 3.6 to 20.9\%) contributes to the growth of coarseness of the humified layer by $5 \mathrm{~cm}$ and the total potassium content by $0.01 \%$ ( see Table 5). Total potassium content varies in the range of values from 0.012 to $0.055 \%$, and the coarseness of the humified layer of the soil profile varies from 10 to 91 $\mathrm{cm}$.

\section{Discussion}

The productivity of pine plantations is most influenced by the properties of the 0-60-centimeter layer of soil, which combines the humus-eluvial and partially the transitional horizons to the soil rock. This dependence is particularly and clearly seen in the Polissia and is determined by the better supply of nutrients to the accumulative horizons. It is clear that the soil processes associated with the synthesis, transformation and accumulation of organo-mineral substances are the most intensive in the humus horizons of the soil, and the main element of their absorption is clay minerals that make up the fraction of physical clay. In climatic zones with a pronounced seasonal deficit of soil moisture (the Forest-steppe and especially the Northern Steppe) and the non-washing type of soil water regime, as a result of which the leaching of nutrients outside the soil profile turns out to be quite moderate, the height of pine plantations is influenced by clay content in the soil layer which is deeper than half a meter $(65-80 \mathrm{~cm})$. That is, the deeper the saturation of the soil profile with clay particles with better water-retaining capacity than in sandy ones, the higher the increase in the productivity of pine stands in the abovementioned natural zones.

A generalization of the data showed that in fresh conditions of moisture, regardless of the type of soil and natural zone, there is a straightforward close relationship between the height of pine trees and the content of physical clay in the upper 60-cm layer of light soils, brought to $99.9 \%$ probability. In such a way, the productivity of pine forests, which in Ukraine are mainly formed on sandy soils, depends on their clay content. Thus, an increase in the content of physical clay in the soil layer of $0-60 \mathrm{~cm}$ by $1 \%$ (within PC content between 4.2 and 16\%) contributes to an increase in the height of pine stands (at the age of 70 years) by $1.2 \mathrm{~m}$. The increase in productivity of stands is due to a better ability of sandy soils containing more clay to accumulate more moisture and nutrients compared to pure quartz sand. Moreover, in different natural zones, the emphasis on the influence of clay particles on the productivity of pine forests is changing. In areas with a pronounced seasonal moisture deficit (the Forest-Steppe and the Northern Steppe), the ability of clay particles to accumulate moisture is a determining factor in increasing the height of tree stands, while in areas of sufficient moisture (the Polissia), such determining factor is their ability to accumulate nutrients. The content of physical clay particles is one of the main markers of forest site capacity regarding soils with light texture.

In light soils, the physical clay content is functionally related to such indicators as the coarseness of the humified layer and total potassium content (see Table 5), which in turn also affect the productivity of pine stands. At the same time, if physical clay content in sandy soils of various natural zones is very similar (the difference between the types is only $0.4-0.6 \%$ ), then they differ in the coarseness of the 
humified layer and the potassium content. Ancient alluvial and fluvioglacial sands, which are mainly soil-forming rocks for the studied soils, were formed under the influence of water flows and passed through the hygromorphic stage of development (as evidenced by ferruginous horizons and other signs of gleying). They are characterized by very similar particle-size distribution, in particular, the content of physical clay. As for potassium, its content depends not only on the total amount of clay particles but also on the mineralogical composition of sands and the modern soil water regime, which differ significantly in different natural zones.

The humus content of the soil profile is determined by even a greater number of factors (a sufficient amount of phytomass, its species composition, the duration of optimal humufication conditions, the mineralogical and granulometric composition of soil-forming rocks, the composition of exchangeable cations in the SCEC (soil-colloidal absorbing complex), the composition and activity of microbiocenosis, etc.) are closely related to zonal climatic, geomorphological and orographic conditions, human influence, etc. That is why potassium content and the coarseness of the humified layer of soil profile in sandy soils of different zones differ, which causes a weakening of their relationships with the productivity of pine stands when summarizing the data, but these relationships remain reliable.

Despite the fact that the studied types of sandy soils differ in the content of total potassium and the value of the coarseness of the humified layer, at the same time they are characterized by a similar forest growth effect, which is manifested by a rather high productivity (on average from the II to the higher growth classes) of pine stands. Notice that within certain TGC (typological forest growth conditions) the nature of changes in these indicators is unidirectional and regular, and their correlation with the productivity of pine stands is statistically valid (at $99.9 \%$ probability level), which confirms the correctness of the choice of these indicators as markers of forest site capacity of light texture soils.

In such a way, forest site capacity of grey forest soils with light granulometric composition forming the pine series of habitats in Polissia, the Forest-Steppe and the Northern Steppe increases progressively as: shifting the particle size distribution in the system of 'soil-subsoil' in the transition from sand to claysand and light sandy loam, increasing the coarseness of the humified layer and the content of the general form of $\mathrm{K}_{2} \mathrm{O}$. The increase in forest site capacity of the soils is accompanied by an increase in the productivity level of pine stands on average by one growth class, from the II to the I (Ia) one. The works by Vilček (2008, 2013b), Vilček \& Torma (2016a, 2016b). Torma et al. (2014, 2018), Vilček et al. (2013) present the need to analyze soil properties and landscape parameters.

\section{Conclusion}

Some of the common types of sandy soils in Ukraine, where the pine series is developed, are grey forest soils on fluvioglacial (glacial) sands in the Polissia and grey forest soils on ancient alluvial sands in the Forest-Steppe and the Northern Steppe. These soils, due to their light texture, are characterized by a generally low level of agronomic site capacity, unlike forest soils, which are quite sufficient to provide normal and even high energy growth of oligotrophic tree species, especially Scots pine and European white birch, Betula pubescens, reaching a significant level of productivity on these soils (from the II to the higher growth classes).

The grey forest soils of the Polissia, the Forest-Steppe and the Northern Steppe, although they differ in the genesis of their soil-forming rocks, as well as in typical and zonal belongings, at the same time they are united by an important general characteristic, light texture, determining the similarity of physical, physico-chemical and agrochemical indicators and, in general, forest site capacity.

The package of markers for assessing the forest site capacity of sandy soils (as pine habitats) under conditions of sufficient moisture level (the fresh - rather fresh forest types) includes the following soil indicators: physical clay content, the coarseness of the humified layer of soil profile and $\mathrm{K}_{2} \mathrm{O}$ content. These indicators of the soil quality are the main (most informative) indicators, but further additional indicators may ones be such as: humus content, $\mathrm{P}_{2} \mathrm{O}_{5}$ and exchangeable cations, of which, $\mathrm{Ca}^{2+}$ will come first of all.

\section{Acknowledgments}

This work was supported by the Slovak Research and Development Agency under contract No. APVV15-0406, and a Scientific Grant Agency of the Ministry of Education of the Slovak Republic and the Slovak Academy of Sciences under contract No. VEGA 1/0059/19. 


\section{References}

Bautista-Cruz, A., del Castillo, R. F., Etchevers-Barra, J. D., Gutiérez-Castorena, del C., Baez, A. (2012). Selection and interpretation of soil quality indicators for forest recovery after clearing of a tropical montane cloud forest in Mexico. Forest Ecology and Management, 277, 74-80. https://doi.org/10.1016/j.foreco.2012.04.013

Błońska, E., Januszek, K. (2013). Usability of enzyme activity in estimation of forest soil quality. Folia Forestalia Polonica, Seria A, Forestry, 55(1), 18-26. DOI: 10.2478/ffp-2013-0003

Karpachevsky, L. O., Nikonov, V. V. (2004). Lesnoje pochvovedenie v XXI veke [Forest soil science in the XXI century]. Forest science, 4, 3-5. ISSN 0024-1148. http://naukarus.com/lesnoe-pochvovedenie-v-xxi-veke

Lisnyak, A. (2013). Ocinjuvanija suchasnogo stanu erodovanych gruntiv jaruzhno-balkovoj sistemy "Mitrishin Jar" Livoberezhnogo Lisostepu Ukrajiny [Estimation of the current state of eroded soils of the Northern-Baltic beam system "Mithrysyn Yar" of the Left Bank Forest-steppe Ukraine]. Arboriculture and agroforestry, 122, $103-109$.

Medvedev, V., Plisko, J. V. (2006). Bonitirovka i kachestvennaj ocenka pachotnych zemelj Ukrajiny. [Validation and qualitative assessment of arable lands of Ukraine]. Kharkov: Ed. "13 printing house".

Pogozhev, E. (2006). Mineralogicheskij sostav krupnych frakcii podzolov I podzolistych pochv Srednej tajgi (na primere pochv Kenozerskogo nacionalnogo parka) [Mineralogical composition of large fractions of podzols and podzolic soils of the Middle taiga (on the example of the soils of the Kenozero National Park)]. Thesis, 267 pp.

Rogovsky, S. (2008). Zalisennja maloproduktivnych zemel silskogospodarskogo priznachenija: problemy i perspektivy. [Fighting of unproductive agricultural lands: problems and perspectives]. Scientific Bulletin of NLTU of Ukraine. Lviv: RVB NLTU of Ukraine, 18.10, 18-22. ISSN 1994-7836

Tokavchuk, V. (2011). Ocenka svojstv serych pochv pri vosstanovlenii lesa na zalezhnych zemljach lesostepnoj zony [Evaluation of the properties of gray soils in the restoration of forests on the dependent lands of the forest-steppe zone], Krasnoyarsk, 18 pp.

Torma, S., Vilcek, J., Adamisin, P., Huttmanova, E., Hronec, O. (2014). Influence of natural zeolite on nitrogen dynamics in soil. Turk J Agric For., 38, 739-744. DOI: 10.3906/tar-1311-13

Torma, S., Vilček, J., Lošák, T., Kužel, S., Martensson, A. (2018). Residual plant nutrients in crop residues - an important resource. Acta Agriculturae Scandinavica, Section B — Soil \& Plant Science, 68(4), 358-366. doi:10.1080/09064710.2017.1406134

Vilček, J. (2008). Climate changes and their impact on possibilities of sugar beet growing in Slovakia. Listy cukrovarnícke a řepářské, 124 (3), 78-81. http://www.cukr-listy.cz/on_line/2008/pdf/78-80.PDF

Vilček, J. (2011): Potenciály a parametre kvality pol’nohospodárskych pôd Slovenska [Potential and quality parameters of farmland in Slovakia]. Geografický časopis, 63(2), 133-154. https://www.sav.sk/journals/uploads/03101342Vil\%C4\%8Dek.pdf

Vilček, J. (2013a). Bioenergetic potential of agricultural soils in Slovakia. Biomass and Bioenergy, 56, 53-61. DOI:10.1016/j.biombioe.2013.04.030

Vilček, J. (2013b).: Land selection for cultivation of sugar beet in Slovakia. Listy cukrovarnícke a řepářské, 129(7-8), 215218. http://www.cukr-listy.cz/on_line/2013/PDF/215-218.pdf

Vilček, J., Torma, S., Adamišin, P., Hronec, O. (2013). Nitrogen sorption and its release in the soil after zeolite application. Bulg. J. Agric. Sci., 19, 228-234. https://www.agrojournal.org/19/02-08.pdf

Vilček, J., Torma, S. (2016a). Winter wheat (Triticum aestivum L.) growth potential in the Slovak rural landscape. Archives of Agronomy and Soil Science, 62(2), 235-245. doi:10.1080/03650340.2015.1043899

Vilček, J., Torma, S. (2016b). Characterization of Soils in Slovakia for Sugarbeet (Beta vulgaris L.) Cultivation Using Geographic Information system (GIS). Sugar Tech, 18(5), 488-492. doi: 10.1007/s12355-015-0419-5

Vilček, J., Koco, Š. (2018). Integrated index of agricultural soil quality in Slovakia. Journal of Maps, 14(2), 68-76. doi:10.1080/17445647.2018.1428233

Vilček, J., Koco, S., Torma, Š., Lošák, T, Antonkiewicz, J (2019). Identifying Soils for Reduced Tillage and No-Till Farming Using GIS. Pol. J. Environ. Stud. Vol. 28, No. 4, 2407-2413. DOI: 10.15244/pjoes/90787

Zonn, S. V., Karpachevsky, L. O. (1987). Problemy lesnogo pochvovedenija i sovremennyje metody lesorastitelnoj ocenki pochv [Problems of forest pedology and modern methods of soil forest growing properties evaluation]. Pochvovedenije [Soil science], (Moscow) 9, 6-16. ISSN 0032-180X 